\title{
Dietary Agaricus blazei Spent Substrate Improves Disease Resistance of Nile Tilapia (Oreochromis niloticus) against Streptococcus agalactiae In Vivo
}

\author{
Po-Tsang Lee ${ }^{1,+}+\mathbb{D}$, Yu-Sheng $W u^{2,+} \mathbb{D}$, Chung-Chih Tseng ${ }^{3,4} \mathbb{D}$, Jia-Yu Lu ${ }^{5, *}$ and Meng-Chou Lee ${ }^{1,6,7, * \mathbb{D}}$
}

Citation: Lee, P.-T.; Wu, Y.-S.; Tseng, C.-C.; Lu, J.-Y.; Lee, M.-C. Dietary Agaricus blazei Spent Substrate Improves Disease Resistance of Nile Tilapia (Oreochromis niloticus) against Streptococcus agalactiae In Vivo. J. Mar. Sci. Eng. 2022, 10, 100. https:// doi.org/10.3390/jmse10010100

Academic Editor: Caterina Faggio

Received: 23 November 2021

Accepted: 10 January 2022

Published: 12 January 2022

Publisher's Note: MDPI stays neutral with regard to jurisdictional claims in published maps and institutional affiliations.

Copyright: (C) 2022 by the authors. Licensee MDPI, Basel, Switzerland. This article is an open access article distributed under the terms and conditions of the Creative Commons Attribution (CC BY) license (https:// creativecommons.org/licenses/by/ $4.0 /)$.
1 Department of Aquaculture, National Taiwan Ocean University, Keelung City 20224, Taiwan; leepotsang@email.ntou.edu.tw

2 Department of Aquaculture, National Pingtung University of Science and Technology, No. 1, Xue-Fu Road, Neipu Township 912301, Taiwan; wuys0313@mail.npust.edu.tw

3 Zuoying Branch of Kaohsiung Armed Forces General Hospital, Kaohsiung City 81342, Taiwan; caviton@gmail.com

4 Institute of Medical Science and Technology, National Sun Yat-sen University, Kaohsiung City 80424, Taiwan

5 Nutrition Room of Zuoying Branch of Kaohsiung Armed Forces General Hospital, Kaohsiung City 81342, Taiwan

6 Center of Excellence for Ocean Engineering, National Taiwan Ocean University, Keelung City 20224, Taiwan

7 Center of Excellence for the Oceans, National Taiwan Ocean University, Keelung City 20224, Taiwan

* Correspondence: a0918528453@gmail.com (J.-Y.L.); mengchoulee@email.ntou.edu.tw (M.-C.L.)

+ These authors contributed equally to this work.

\begin{abstract}
This study evaluated the effects of the feeding of spent mushroom substrate from Agaricus blazei on Nile tilapia (Oreochromis niloticus). The safety of $0-1000 \mu \mathrm{g} / \mathrm{mL}$ A. blazei spent substrate water extract (ABSSE) was demonstrated in the primary hepatic and splenic macrophages and the THK cell line (a cell line with characteristics of melanomacrophages) using a cytotoxicity assay. Here, 10 $\mu \mathrm{g} / \mathrm{mL}$ of crude ABSSE promoted the phagocytic activity of macrophages and THK cells. Stimulating ABSSE-primed THK cells with lipopolysaccharides or peptidoglycan resulted in higher expression levels of four cytokine genes (e.g., interleukinz (IL)-1 $\beta, I L-12 b, I L-8$ and tumor necrosis factor $\alpha$ $(T N F \alpha)$ ) and one cytokine gene (TNF $\alpha)$, respectively. An in vitro bacterial growth inhibition assay demonstrated that ABSSE could inhibit the growth of Streptococcus agalactiae. In the first feeding trial, Nile tilapia were fed with experimental feed containing 0,1 , or $5 \%$ of A. blazei spent substrate (ABSS) for seven and fourteen days followed by bacterial challenge assay. The best result was obtained when Nile tilapia were continuously fed for seven days on a diet containing $1 \%$ ABSS, with the survival rate being higher than in groups with $0 \%$ and $5 \%$ ABSS after challenge with S. agalactiae. In the second trial, fish were fed diets supplemented with $0 \%$ or $1 \%$ ABSS for seven days, and then all the groups were given the control feed for several days prior to bacterial challenge in order to investigate the duration of the protective effect provided by ABSS. The results showed that the protective effects were sustained at day 7 after the feed was switched. Overall, spent mushroom substrate from $A$. blazei is a cost-effective feed additive for Nile tilapia that protects fish from S. agalactiae infection.
\end{abstract}

Keywords: immunoregulator; Agaricus blazei; spent substrate; Streptococcus agalactiae; gene expression

\section{Introduction}

Aquaculture has grown extensively since the late 1980s and continues to supply fish for human consumption. According to the Food and Agriculture Organization (FAO), global aquaculture production of farmed aquatic animals increased at a rate of 5.3\% per year between 2001 and 2018. More specifically, aquaculture production supplied over 82.1 million tons of food in 2018 [1], and is expected to reach 109 million tons in 2030, which is a $32 \%$ (26 million tons) increase from 2018 [1]. Obviously, aquaculture will continue to be a main source of global fish production. 
Among the fish species cultured, tilapia is regarded as the second most widely farmed fish in the world after carp and provides precious animal protein for humans [2]. There are only about 10 species of commercial tilapia culture, and globally the Nile tilapia is the most important farmed tilapia species [2]. The global expansion of tilapia production is driven by its high growth rate, suitability for various aquatic habitats, tolerance to a wide range of environmental factors (e.g., temperature, water salinity, and dissolved oxygen), selective breeding, strong resistance to disease, and potential to replace marine fish products [3]. With such advantages, global farmed tilapia production increased by $3.3 \%$ in 2020, surpassing 6 million tons for the first time despite the impact of COVID-19 [3]. The intensification of aquaculture has increased the distribution and spread of infectious agents, such as Streptococcus agalactiae [4], Streptococcus iniae [4,5], Aeromonas hydrophila [6], Edwardsiella tarda [7], Flavobacterium asiatica [8], Lactococcus garvieae [9], and tilapia lake virus (TiLV) [10], which is a major barrier against the growth of aquaculture [11].

Recently, the tilapia culture industry has been progressively threatened by disease, resulting in high mortality and great economic losses. Streptococcus is thought to be the worst disease for tilapia worldwide, and infectious diseases caused by S. agalactiae are commonly reported in tilapia culture, which can lead to significant economic losses [12]. The pervasiveness and seriousness of pathogens can be influenced by environmental conditions such as high ammonia, low dissolved oxygen, and warm water temperature [13]. The threat from bacterial diseases in tilapia culture has increased the use and misuse of antibiotics, which adversely affect the environment and human health and facilitate the emergence of antibiotic-resistant bacteria.

Agaricus blazei is an edible mushroom native to Brazil that has become of interest to various areas of medical research, as it has shown remarkable immunomodulating and tumoricidal effects [14]. A. blazei has drawn substantial attention due to its health-promoting and medicinal properties [15], such as its immunomodulation [16], antihypertensive [17], antihypercholesterolemia [18], weight-controlling [18], hepatic disease-controlling [19], and anticancer [20] effects. The amount of byproducts and spent substrate from mushroom production has increased dramatically with increased demand [21,22]. The annual global mushroom yield is estimated to be over 25 million tons [23], creating a large amount of spent mushroom substrate that is detrimental to the environment. Efforts to overcome this issue have focused on recycling and reusing spent mushroom compost, e.g., enzyme recovery [24], biodegradation of polycyclic aromatic hydrocarbons [25], phenol oxidation [26], pentachlorophenol decontamination [27], providing animal feed for ruminants [28], and biosorption of heavy metals [23].

Immunostimulants and immunoregulators have attracted much attention in aquaculture since they are famous for their environmentally friendly properties and ease of use [29]. As prophylactic and protective substances, they are frequently utilized in aquaculture to promote the health and disease resistance of cultured animals [30]. Recently, many functional feed additives for managing the health of aquatic animals have been developed [31]. These additives aim to modulate the immune response and disease resistance of cultured animals to infectious microbes, thereby reducing the use of antibiotics and disease-related economic losses [32,33]. So far, only a few papers [31,34] have reported on the use of spent mushroom substrate in aquatic animals as a source of immunomodulators. Therefore, we conducted in vitro and in vivo experiments to examine the potential of $A$. blazei spent substrate (ABSS) to be used as an immunomodulator for Nile tilapia.

\section{Materials and Methods}

\subsection{Experimental Fish}

A batch of healthy Nile tilapia (Oreochromis niloticus) was transported from the aquatic center at National Taiwan Ocean University (NTOU; Keelung, Taiwan) to the laboratory and acclimatized for seven days to the laboratory conditions. Fish were kept in 1.8 ton freshwater in 2-ton fiberglass-reinforced plastic (FRP) tanks, and 30\% of the tank water was renewed with fresh dechlorinated water every 20-24 h. Fish received pelleted feed (Tairoun 
Products Company Ltd., Taipei, Taiwan) two times a day at 3-5\% of fish body weight. Water parameters were ensured as follows: temperature at $28 \pm 2{ }^{\circ} \mathrm{C}, \mathrm{pH}$ at $7.0 \pm 0.2$, and dissolved oxygen at $5.0 \pm 0.5 \mathrm{mg} / \mathrm{L}$. Concentrations of ammonia- $\mathrm{N}$ and nitrite-N in the water were maintained at no more than 0.10 and $0.05 \mathrm{ppm}$, respectively. The animal experiments were approbated by the Institutional Animal Care and Use Committee at NTOU (Approval number: 109005). Moribund fish with unstable, disoriented swimming actions from bacteria challenge assays were euthanized by using an overdose of MS222 (Sigma-Aldrich, Massachusetts, USA).

\subsection{Preparation of ABSS and Crude Extract Preparation}

The main elements for culturing $A$. blazei are calcium, rice bran, sponges, herbs, straw, cotton, sawdust, poultry manure, wheat bran, and agricultural byproducts rich in lignocellulosic complexes $[35,36]$. Protein-rich ingredients such as soybeans can be added to growth substrate to stimulate $A$. blazei production and reduce waste [37]. Therefore, in this study, a mixture of brown rice, rice bran, soybeans, and calcium carbonate was used to grow A. blazei, and the fermented spent substrate was applied to evaluate its ability to promote the immune status of Nile tilapia and disease resistance to $S$. agalactiae infection. The ABSS powder was provided by Yeeder Biotechnology Co., Ltd. (New Taipei City, Taiwan). The substrate comprised brown rice (70\%), rice bran $(20 \%)$, soybeans $(8 \%)$, and calcium carbonate $(2 \%)$. The time of fermentation was approximately 60 days, and the fermentation temperature was controlled at $24 \pm 1{ }^{\circ} \mathrm{C}$ (Taiwan patent no. I284502). The moisture, ash, fiber, crude protein, and crude lipid content in ABSS were measured by standard methods from the Association of Analytical Communities (AOAC) [38].

Crude extracts from ABSS were obtained by soaking $10 \mathrm{~g}$ of ABSS powder in $90 \mathrm{~mL}$ of water in a glass bottle, followed by incubation at $40{ }^{\circ} \mathrm{C}$ for $3 \mathrm{~h}$. The tube was slowly inverted several times during extraction. Then, the tube was spun at $9900 \times \mathrm{g}$ for $10 \mathrm{~min}$ at $4{ }^{\circ} \mathrm{C}$ (Allegra X-30R, Beckman Coulter, California, USA), and the supernatant was transferred to a clean sterile glass bottle. This supernatant, A. blazei spent substrate extract (ABSSE), was filtered through a filter with $0.2 \mu \mathrm{m}$ pore size, freeze-dried, then kept at $4{ }^{\circ} \mathrm{C}$ until its use for the in vitro experiments.

The contents of monosaccharide and polysaccharide as well as monosaccharide elements within the polysaccharides of the ABSSE were resolved using nuclear magnetic resonance (NMR) spectrometry (Sugarlighter, Taipei, Taiwan). The $\beta$-glucan content was analyzed using a $\beta$-glucan assay kit (Megazyme, Bray, Ireland), following the manufacturer's instructions. The sulfate content in ABSSE was analyzed using the $\mathrm{BaCl}_{2}-$ gelatin turbidity method described previously [39].

\subsection{In Vitro Trials}

\subsubsection{Cell Viability Assay}

Macrophages were isolated from liver and spleen followed by the protocol described earlier [40] and were used to examine the effects of the ABSSE on cell viability. Liver and spleen samples from three tilapia (500 $\pm 50 \mathrm{~g}$ ) were perfused for $15 \mathrm{~min}$ via a portal vessel using a solution $\left(10 \mathrm{mmol} / \mathrm{L}\right.$ glucose, $2.68 \mathrm{mmol} / \mathrm{L} \mathrm{KCl}, 0.7 \mathrm{mmol} / \mathrm{L} \mathrm{Na}_{2} \mathrm{HPO}_{4}-12 \mathrm{H}_{2} \mathrm{O}$, $0.5 \mathrm{mmol} / \mathrm{L}$ EDTA-2Na, $137 \mathrm{mmol} / \mathrm{L} \mathrm{NaCl}$, and $10 \mathrm{mmol} / \mathrm{L} \mathrm{HEPES}$ in calcium-free water). The splenic or hepatic tissues were then chopped into small pieces and incubated for $30 \mathrm{~min}$ in a buffer contains $0.05 \%$ collagenase IV (Sigma-Aldrich, St. Louis, MO, USA). The solution was then pushed through a filter with $100 \mu \mathrm{m}$ pore size to remove undigested tissues and the cells in the flow through were segregated using 16\% Nycodenz gradient medium followed by gradient centrifugation in 30\% and 50\% Percoll solution (GE Healthcare, Chicago, IL, USA). The desired cell fraction was aspirated and cultured in RPMI 1640 medium (Gibco, Waltham, MA, USA). Ten million macrophages and the THK cells [41] were cultured in a culture medium containing $0,10,100$, or $1000 \mu \mathrm{g} / \mathrm{mL}$ ABSSE. The cell proliferation assay was conducted at 12 and $24 \mathrm{~h}$ using Kit-8 a cell counting kit (CCK-8; Bimake, Houston, TX, USA) following the manufacturer's instructions. 


\subsubsection{Analysis of Phagocytic Activity}

A phagocytosis assay was performed using pHrodo Green Escherichia coli BioParticles Conjugate (Life Technologies, Carlsbad, CA, USA) as previously described [42]. Briefly, hepatic and splenic macrophages from three tilapia $(500 \pm 50 \mathrm{~g})$ were dispensed into 96-well plates $\left(1 \times 10^{6}\right.$ cells per well $)$ and allowed to settle overnight at $28^{\circ} \mathrm{C}$. Cells were then incubated with 0, 10, 100, and $1000 \mu \mathrm{g} / \mathrm{mL}$ ABSSE for 12 and $24 \mathrm{~h}$ in an RPMI-1640based medium. At indicated time points, the cell medium was substituted with $200 \mu \mathrm{L}$ BioParticles solution in Hank's Balanced Salt Solution (Gibco), then cells were incubated for $2 \mathrm{~h}$ at $28{ }^{\circ} \mathrm{C}$. A similar phagocytosis assay was conducted using THK cells. THK cells were cultured with L-15 medium (Gibco) supplemented with $10 \%(v / v)$ fetal bovine serum (FBS, Corning), antibiotics mix (penicillin $(100 \mathrm{U} / \mathrm{mL}$ )/streptomycin, $100 \mu \mathrm{g} / \mathrm{mL}$, Gibco), and heparin (10 U/mL, Sigma-Aldrich)). THK cells were treated with or without $10 \mu \mathrm{g} / \mathrm{mL}$ ABSSE prior to the addition of BioParticles. Relative fluorescence units (RFU) were monitored at an excitation wavelength of $509 \mathrm{~nm}$ and an emission wavelength of $533 \mathrm{~nm}$ using a spectrofluorometer (SPECTRA max GEMINI XPS; Molecular Devices, San Jose, CA, USA).

\subsubsection{Gene Expression Analysis}

THK cells were allowed to settle in a 12-well plate at a density of $1 \times 10^{6}$ cells per well in triplicate. On the following day, the THK cell line was primed with 0 (named control group) or $10 \mu \mathrm{g} / \mathrm{mL}$ of ABSS (named ABSSE-only group) for $24 \mathrm{~h}$ and subjected to gene expression analysis. In parallel, THK cells were pretreated with culture medium with or without ABSSE and then stimulated with $50 \mu \mathrm{g} / \mathrm{mL}$ lipopolysaccharides (LPS, Sigma-Aldrich) for $24 \mathrm{~h}$. The former group was named "ABSSE + LPS" and the latter "control + LPS".

Another similar experiment was performed, except the bacterial ligand peptidoglycan (PGN, $50 \mu \mathrm{g} / \mathrm{mL}$, Invivogen, San Diego, CA, USA) was used after priming the THK cells with ABSSE, as previously described.

Total RNA was extracted from the cells after treatment and cDNA was synthesized using an iScript gDNA Clear cDNA Synthesis Kit (Bio-Rad, Berkeley, CA, USA) as described previously [43]. Quantitative real-time PCR (qRT-PCR) was conducted using the primers listed in Table 1. Briefly, the qRT-PCR reaction $(20 \mu \mathrm{L})$ comprised $4 \mu \mathrm{L}$ of cDNA, $10 \mu \mathrm{L}$ of RealQ Plus $2 \times$ Master Mix (Ampliqon A/S), $1 \mu \mathrm{L}$ of forward and reverse primers, and $4 \mu \mathrm{L}$ of nuclease-free water (Invitrogen). The PCR program was set as follows: $94{ }^{\circ} \mathrm{C}$ for $15 \mathrm{~min}$, followed by 40 cycles of $15 \mathrm{~s}$ at $94{ }^{\circ} \mathrm{C}$ and $1 \mathrm{~min}$ at $60^{\circ} \mathrm{C}$. The expression levels of the genes of interest were normalized to those of beta-actin ( $\beta$-actin) and presented as fold changes relative to the control group. The transcript level of the gene of interest was normalized to the mRNA level of $\beta$-actin and $\log 2$-transformed to improve the normality of data before statistical analysis [44].

Table 1. Primers used in this study.

\begin{tabular}{cccc}
\hline Gene & Forward $\left(\mathbf{5}^{\prime} \rightarrow \mathbf{3}^{\prime} \mathbf{)}\right.$ & Reverse $\mathbf{( 5}^{\prime} \rightarrow \mathbf{3}^{\prime} \mathbf{)}$ & Accession $\mathbf{N u m b e r}$ \\
\hline $\boldsymbol{\beta}$-actin & TCCTTCCTTGGTATGGAATCC & GTGGGGCAATGATCTTGATC & KJ126772 \\
IL-1 $\boldsymbol{\beta}$ & CAGTGAAGACCGCAAAGTGC & TATCCGTCACCTCCTCCAG & XM_019365841 \\
IL-8 & TCGCCACCTGTGAAGGCAT & TCCTTTTCAGTGTGGCAATGAT & XM_019359413 \\
IL-12b & CAACAGTGACAATCAAATAATTAATAT & CGTTATGTTTGTTCACTGTGCA & XM_019364048 \\
TNF- $\alpha$ & GAACACTGGCGACAAAACAGA & TTGAGTCGCTGCCTTCTAGA & AY428948 \\
\hline
\end{tabular}

\subsubsection{Bacterial Inhibition Assay}

S. agalactiae used in the present study was isolated from diseased tilapia [42]. Bacteria were cultured on tryptic soy agar (TSA, Difco, Franklin Lakes, NJ, USA) for $16 \mathrm{~h}$ at $28{ }^{\circ} \mathrm{C}$ prior to suspension in sterile phosphate-buffered saline (PBS). Then, $100 \mu \mathrm{L}$ of S. agalactiae $\left(1 \times 10^{5}\right.$ colony-forming units $\left.(\mathrm{CFU}) / \mathrm{mL}\right)$ was spread on the TSA followed by inoculation 
of $100 \mu \mathrm{L}$ of ABSSE (50 mg/mL) or water extract from unfermented growth substrate (control) in the holes on the agar, then incubated at $28^{\circ} \mathrm{C}$. The inhibition zone was observed $24 \mathrm{~h}$ post inoculation.

In broth inhibition assay, $100 \mu \mathrm{L}$ of $S$. agalactiae $\left(10^{6} \mathrm{CFU} / \mathrm{mL}\right)$ in tryptone soy broth (TSB, Difco) was mixed with $900 \mu \mathrm{L}$ of TSB with or without $50 \mathrm{mg} / \mathrm{mL}$ of ABSSE, then incubated for $2 \mathrm{~h}$ at $28^{\circ} \mathrm{C}$ on a shaker (150 rpm). Following incubation, some of the $100 \mu \mathrm{L}$ of mixture was spread on TSA and incubated for $16 \mathrm{~h}$ at $28^{\circ} \mathrm{C}$. Colony counts from triplicate plates were recorded.

\subsection{In Vivo Experiments}

\subsubsection{First Feeding Trial}

A commercial tilapia diet from Tairoun Products Co., Ltd. was ground as the base for making experimental feed. Sample 1 was the control diet without additive. Samples 2 and 3 were made by mixing commercial feed with $10 \mathrm{~g}$ ( $1 \%$ total feed weight) or $50 \mathrm{~g}$ (5\% total feed weight) ABSS per kg feed weight. All ingredients were thoroughly mixed and the food was re-extruded using a spaghetti squashing machine. The feeds were dried at $40{ }^{\circ} \mathrm{C}$ for $24 \mathrm{~h}$ in the dark and stored in plastic bags at $-20^{\circ} \mathrm{C}$ until use. The levels of moisture, ash, crude protein, and crude lipid content in the experimental feeds were measured by standard methods [38].

Sixty fish (average weight $65.1 \pm 8.7 \mathrm{~g}$ ) were randomly distributed across three FRP tanks. Fish were fed with experimental diets daily at $3 \%$ of their body weight (BW) for 7 and 14 days. At each time point, 10 fish from each group were intraperitoneal injected with S. agalactiae $\left(1 \times 10^{6} \mathrm{CFU} / \mathrm{g} \mathrm{BW}\right)$ suspension. Moribund or dead fish were removed from the tank each day over 21 days of observation. The survival rate (SR) was calculated as follows: SR $(\%)=($ number of fish survived $/$ number of fish injected $) \times 100$.

\subsubsection{Second Feeding Trial}

Sixty fish (average weight $64.8 \pm 3.7 \mathrm{~g}$ ) were randomly distributed across two FRP tanks. Since the continuous feeding of tilapia with feed containing $1 \%$ of ABSS provided better protection against $S$. agalactiae infection, we aimed to test how long the protective effects lasted after changing the feed to a normal commercial feed without ABSS. To this end, fish were given feed containing $0 \%$ or $1 \%$ ABSS for 7 days, then given a commercial diet for 1, 7, and 14 days prior to bacterial challenge as described above. At each time point after the feed was changed 10 fish from each group were challenged with S. agalactiae by intraperitoneal injection of the bacterial suspension as described in Section 2.4.1.

\subsection{Statistical Analysis}

Cell viability, phagocytic activity, and gene expression between the treatment and control groups were analyzed using one-way ANOVA and Tukey's test in IBM SPSS Statistics Package 22.0 (SPSS Inc., IBM, Chicago, USA). Additionally, paired-sample $t$-tests were performed to analyze the phagocytic activity assays conducted in THK cells and the bacteria counts described in Section 2.3.4.

\section{Results}

\subsection{Proximate Composition of ABSS}

The proximate composition of ABSS is listed in Table 2. ABSS comprised 10.12\% moisture, $4.34 \%$ crude protein, $6.25 \%$ crude lipid, $11.29 \%$ ash, $4.33 \%$ fiber, and $63.67 \%$ nitrogen-free extract. 
Table 2. Approximate composition (\%) of Agaricus blazei spent substrate.

\begin{tabular}{cc}
\hline Moisture & $\mathbf{1 0 . 1 2}$ \\
\hline Ash & 11.29 \\
Crude protein & 4.34 \\
Crude lipid & 6.25 \\
Fiber & 4.33 \\
NFE * & 63.67 \\
\hline * Nitrogen-free extract (NFE) $=100-($ protein $\%+$ lipid $\%+$ total ash $\%+$ fiber content $\%)$.
\end{tabular}

\subsection{Approximate Composition of ABSSE}

The recovery rate of ABSSE was around 10-12\%. The total carbohydrate content for ABSSE was over $95 \%$, with monosaccharide (sucrose) making up $65.4 \%$ of the total carbohydrate content and polysaccharides the remaining 34.6\%. Of the total carbohydrate, $1.08 \%$ was $\beta$-glucan and $6.3 \%$ was sulfated carbohydrate (Table 3 ). The polysaccharide content of ABSSE comprised $62.4 \%$ glucose and $37.6 \%$ galactose (Table 3 ).

Table 3. The composition of the carbohydrate of Agaricus blazei spent substrate extracts.

\begin{tabular}{cc}
\hline Content & Percentage \\
\hline Total carbohydrate $(w / w, \%)$ & $>95$ \\
Sulfate $(\%)$ & 6.3 \\
$\beta$-glucan $(\%)$ & 1.08 \\
Monosaccharide content $(\%)$ & 65.4 (Sucrose) \\
Polysaccharide content $(\%)$ & 34.6 \\
Glucose & 62.4 \\
Galactose & 37.6 \\
Others & 0 \\
\hline
\end{tabular}

\subsection{ABSSE Promotes Proliferation of Hepatic and Splenic Macrophages and the THK Cell Line}

The cell viability of macrophages was used as an indicator of immune activation [45]. There was no obvious cytotoxicity in ABSSE-treated cells, except for at the higher concentrations of ABSSE (100 and $1000 \mu \mathrm{g} / \mathrm{mL}$ ), on splenic macrophages at $12 \mathrm{~h}$ (Figure 1). The highest optical density (OD) values were recorded for $10 \mu \mathrm{g} / \mathrm{mL}$ ABSSE-treated hepatic and splenic macrophages and THK cells (at least at $12 \mathrm{~h}$ ) when compared to other the concentrations. Cell proliferative effects were also seen in $100 \mu \mathrm{g} / \mathrm{mL}$ and $1000 \mu \mathrm{g} / \mathrm{mL}$ ABSSE-treated hepatic macrophages at $12 \mathrm{~h}$, splenic macrophages at $24 \mathrm{~h}$, and in $100 \mu \mathrm{g} / \mathrm{mL}$ ABSSE-treated THK cells at both time points.

\subsection{ABSSE Induce Phagocytic Activity in Hepatic and Splenic Macrophages and THK Cells}

Phagocytic activity significantly increased in $100 \mu \mathrm{g} / \mathrm{mL}$ ABSSE-treated hepatic and splenic macrophages at 24 and $12 \mathrm{~h}$, respectively. Hepatic and splenic macrophages showed the highest phagocytic activities after incubation with $10 \mu \mathrm{g} / \mathrm{mL}$ ABSSE (Figure 2). Therefore, we tested whether the treatment of $10 \mu \mathrm{g} / \mathrm{mL}$ ABSSE would also promote phagocytic activity in THK cells. Indeed, after $24 \mathrm{~h}$ incubation with $10 \mu \mathrm{g} / \mathrm{mL}$ ABSSE, the phagocytic activity was significantly elevated in THK cells (Figure 3).

\subsection{Priming THK Cells with ABSSE Enhances the Expression of Proinflammatory Cytokines When Bacterial Ligands Are Encountered}

Since treating THK cells with ABSSE could promote their proliferation and phagocytic activity, we then tested whether this treatment could also modulate the expression of proinflammatory cytokines in THK cells. As shown in Figure 4, incubating THK cells with $10 \mu \mathrm{g} / \mathrm{mL}$ ABSSE for $24 \mathrm{~h}$ did not induce the transcription of proinflammatory cytokines (see control and ABSSE-only groups). Interestingly, stimulating ABSSE-primed THK cells with LPS resulted in higher expression of interleukins (IL)-1 $\beta, I L-12 b$ (p40), IL-8, and tumor 
necrosis factor (TNF)- $\alpha$ (Figure 4). Similarly, incubating ABSSE-primed THK cells with PGN increased the expression of TNF- $\alpha$ (Figure 5).

(A)
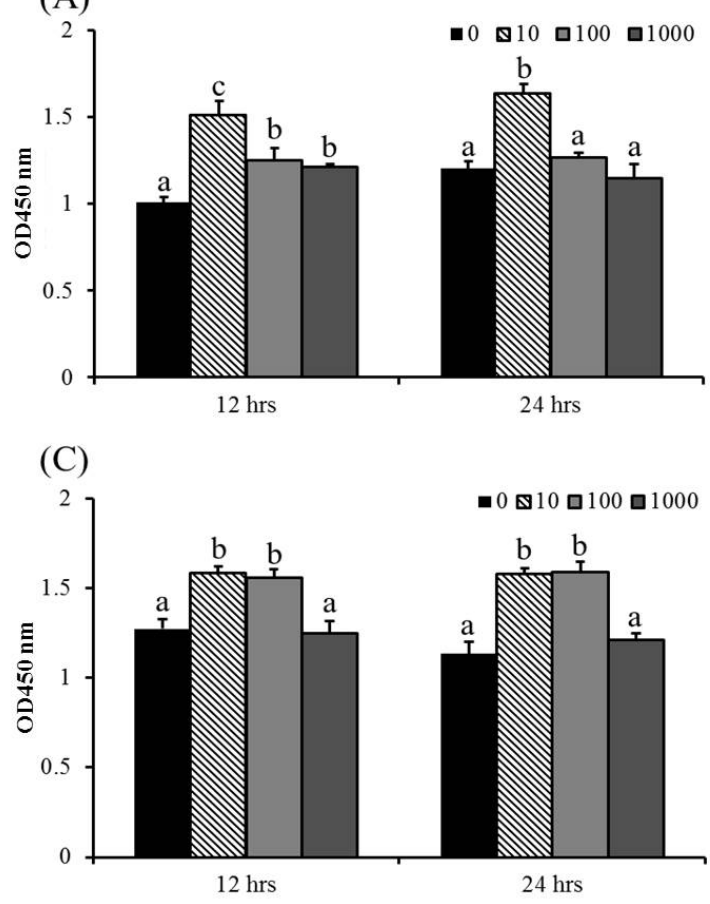

(B)

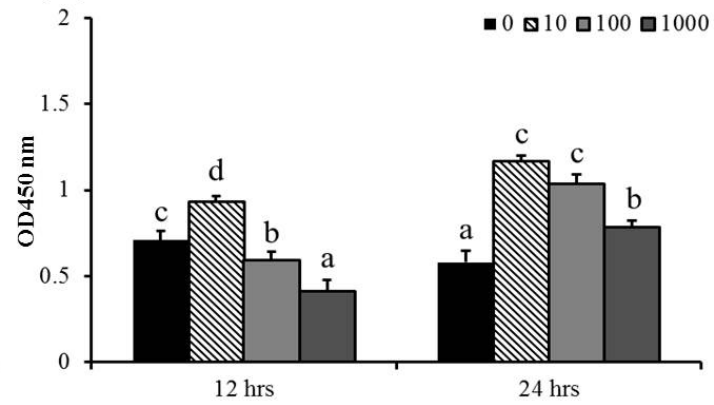

Figure 1. Hepatic (A) and splenic (B) macrophages and THK cell line (C) were treated with L-15 containing 0,10,100, or $1000 \mu \mathrm{g} / \mathrm{mL}$ of Agaricus blazei spent substrate extract (ABSSE). After 12 and $24 \mathrm{~h}$ of treatment, a Cell Counting Kit-8 (CCK-8) was used for evaluating cell viability. The optical density (OD) values are shown as mean + standard error of the mean. Significant differences $(p<0.05$, one-way ANOVA, and Tukey's post hoc test) are indicated by different letters.

(A)

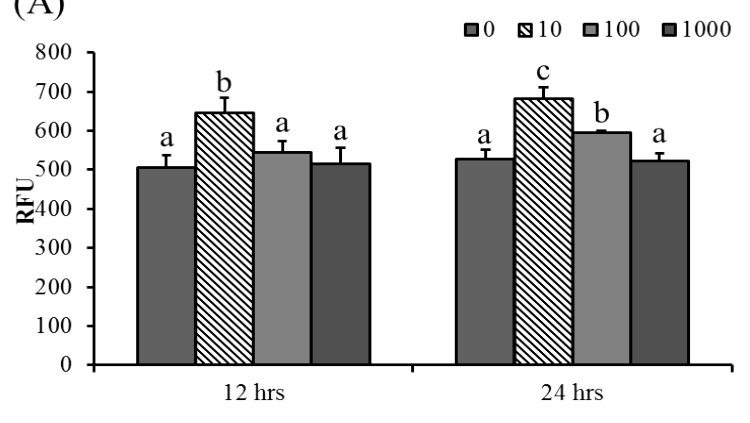

(B)

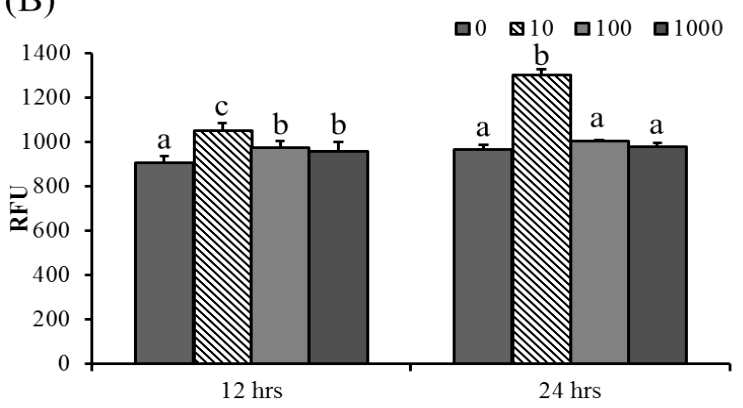

Figure 2. ABSSE induces phagocytic activity in hepatic and splenic macrophages. Hepatic (A) and splenic (B) macrophages were treated with 0, 10, 100, or $1000 \mu \mathrm{g} / \mathrm{mL}$ of Agaricus blazei spent substrate extract (ABSSE) in RPMI 1640 medium for 12 and $24 \mathrm{~h}$ prior to addition of a bioparticle solution. The relative fluorescence units (RFU) were measured and are shown as means + SEM. Significant differences between experimental groups ( $p<0.05$, one-way ANOVA, and Tukey's post hoc test) are indicated by different letters. 


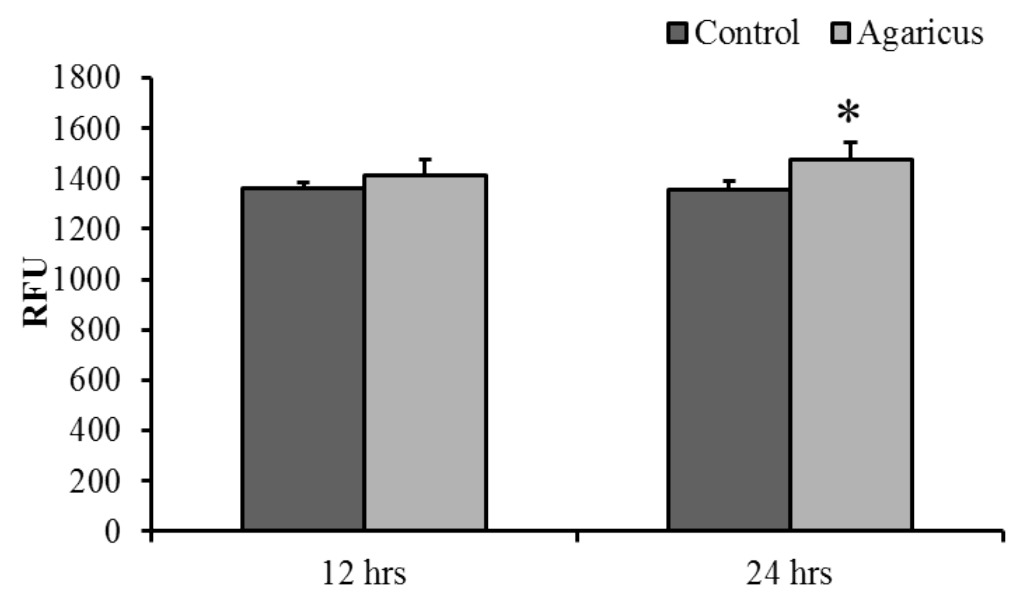

Figure 3. Phagocytic activity in stimulated macrophages. The THK cell line was treated with 0 (control) or $10 \mu \mathrm{g} / \mathrm{mL}$ of Agaricus blazei spent substrate extract (ABSSE) in L-15 for 12 and $24 \mathrm{~h}$ prior to the addition of a bioparticle solution. The relative fluorescence units (RFU) were measured and values are shown as means + standard errors of the mean. A significant difference between experimental and the control group ( $p<0.05$, paired-sample $t$ test) is indicated by an asterisk.

(A)

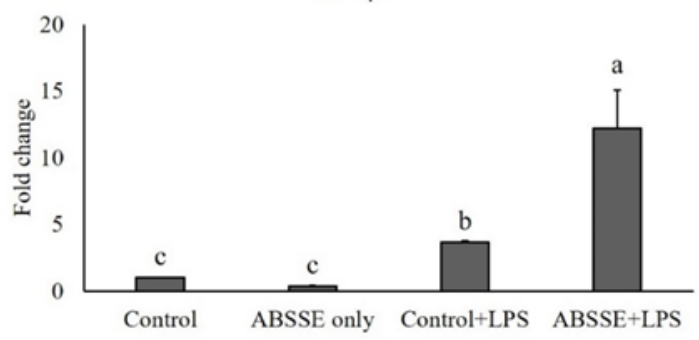

(C)

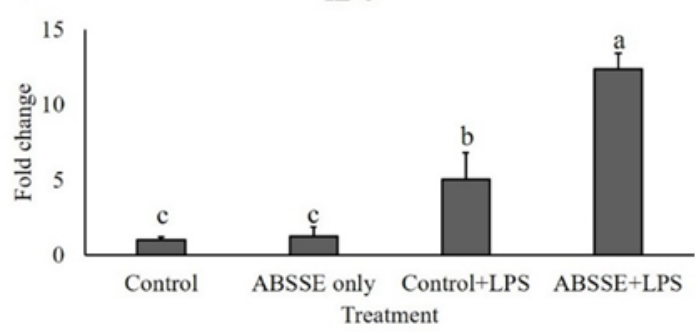

(B)

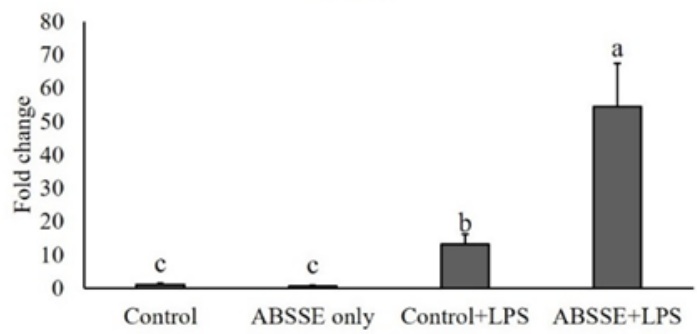

(D)

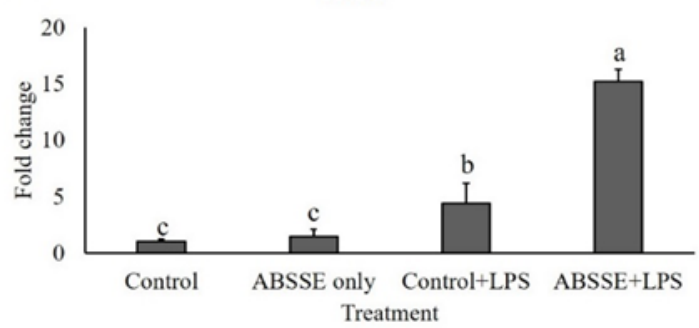

Figure 4. Gene expression analysis of Agaricus blazei spent substrate extract (ABSSE)-primed THK cells after stimulation with lipopolysaccharides (LPS). The THK cell line was primed with 0 (control) or $10 \mu \mathrm{g} / \mathrm{mL}$ of Agaricus blazei spent substrate extract (group ABSSE only) for $24 \mathrm{~h}$ and subjected to gene expression analysis. Additionally, THK cells were pre-treated with L-15 medium or medium containing ABSSE and then stimulated with $50 \mu \mathrm{g} / \mathrm{mL}$ LPS for $24 \mathrm{~h}$. The former group was named "control + LPS" and the later "ABSSE + LPS". Transcript levels of (A) IL-1 $\beta$, (B) IL-12b, (C) IL-8, and (D) TNF- $\alpha$ were analyzed by quantitative real-time PCR. The expression values are shown as means + standard errors of the mean fold change relative to the control group. Significant differences $(p<0.05$, one-way ANOVA, and Tukey's post hoc test) from the control group are indicated by different letters. 
(A)

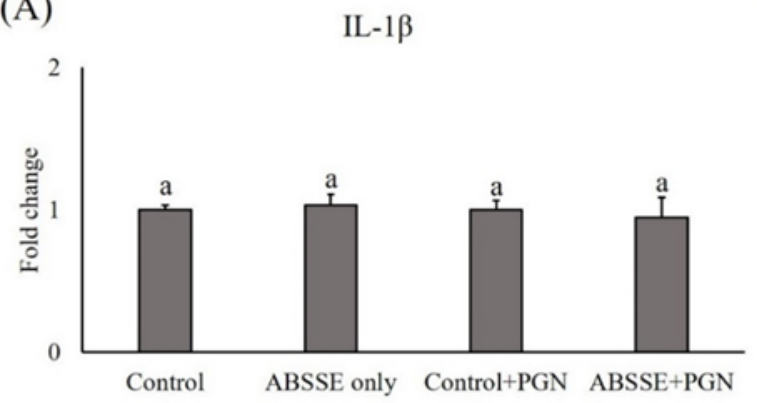

(C)

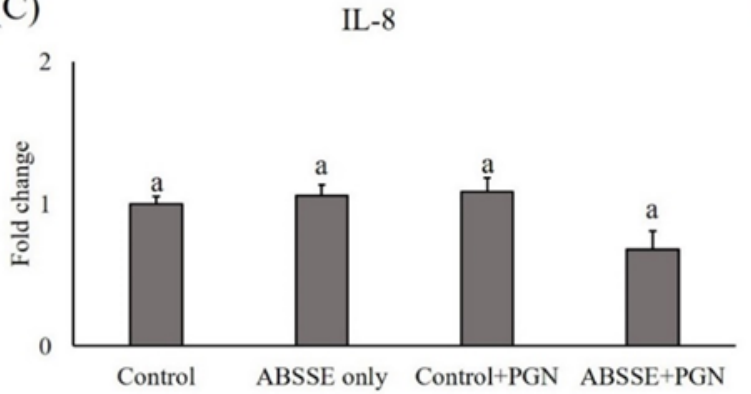

(B)

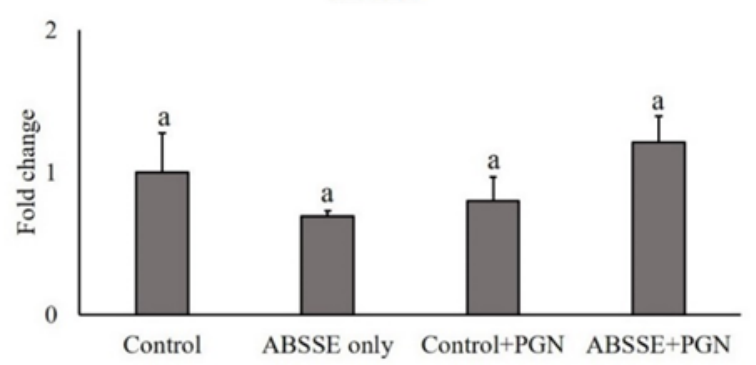

(D)

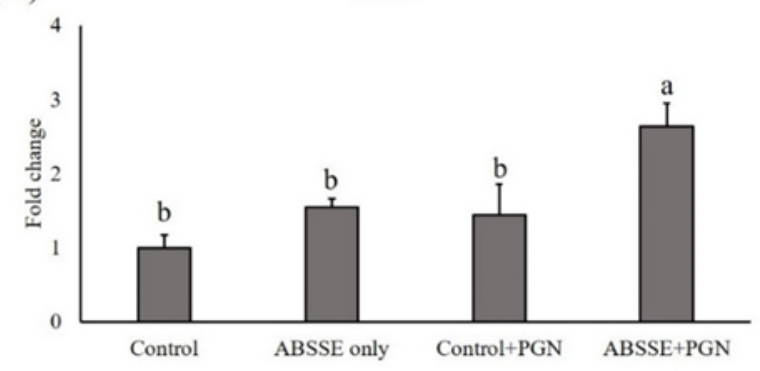

Figure 5. Gene expression analysis of Agaricus blazei spent substrate extract (ABSSE)-primed THK cells after stimulation with peptidoglycan (PGN). The THK cell line was primed with 0 (control) or $10 \mu \mathrm{g} / \mathrm{mL}$ of Agaricus blazei spent substrate extract (group ABSSE only) for $24 \mathrm{~h}$ and subjected to gene expression analysis. Additionally, THK cells were pre-treated with L-15 medium or medium containing ABSSE and then stimulated with $50 \mu \mathrm{g} / \mathrm{mL}$ PGN for $24 \mathrm{~h}$. The former group was named "control + PGN" and the later "ABSSE + PGN". Transcript levels of (A) $I L-1 \beta$, (B) IL-12b, (C) IL-8, and (D) TNF- $\alpha$ were analyzed by quantitative real-time PCR. The expression values are shown as means + standard errors of the mean fold change relative to the control group. Significant differences $(p<0.05$, one-way ANOVA, and Tukey's post hoc test) from the control group are indicated by different letters.

\subsection{ABSSE Inhibits the Growth of S. agalactiae}

As shown in Figure 6, an obvious inhibition zone (approximately $2 \mathrm{~cm}$ in diameter) was seen for the well that was inoculated with ABSSE on an agar swabbed with S. agalactiae (Figure 6A). The equivalent mushroom growth substrate without fermentation was used to make crude extract using the same method as for ABSSE, and there was no inhibition zone for the well that was inoculated with extract from the unfermented growth substrate (Figure 6A). We then cultured S. agalactiae in TSB in the presence or absence of ABSSE and found a significant reduction in the bacterial colony count when $S$. agalactiae was incubated with ABSSE (Figure 6B).

\subsection{Protection of Nile Tilapia against Bacterial Infection}

We evaluated whether oral ingestion of ABSS could provide Nile tilapia protection from S. agalactiae. Three experimental feeds supplemented with $0 \%, 1 \%$, and $5 \%$ ABSS with similar compositions (Table 4) were made for the first feeding trial. Fish were fed experimental feeds continuously for 7 and 14 days prior to bacterial challenge. On day 7 , the highest survival rate was recorded for the group that received feed containing $1 \%$ ABSS $(40 \%)$, followed by the group with 5\% ABSS (30\%). The control diet group had the lowest survival rate (10\%) (Figure 7A). The survival rates did not differ between the control and $1 \%$ ABSS diet groups $(30 \%)$ on day 14 , and the $5 \%$ ABSS group had the lowest survival rate $(20 \%)$ (Figure $7 \mathrm{~B})$. 
(A)

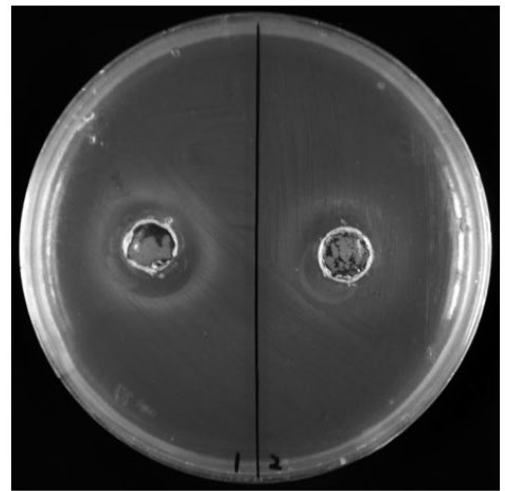

(B)

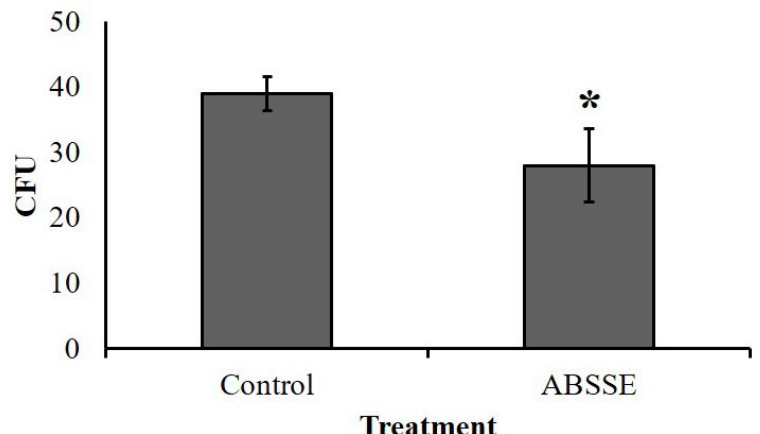

Figure 6. Agaricus blazei spent substrate extract (ABSSE) inhibits the growth of Streptococcus agalactiae. (A) The left and right wells of tryptone soy agar (TSA) that spread with Streptococcus agalactiae were inoculated with $100 \mu \mathrm{L}$ of ABSSE (left, $50 \mathrm{mg} / \mathrm{mL}$ ) or water extract of unfermented growth substrate (right, control) followed by a $24 \mathrm{~h}$ incubation at $28^{\circ} \mathrm{C}$. (B) Here, $100 \mu \mathrm{L}$ of Streptococcus agalactiae $\left(10^{6}\right.$ C.F.U. $\left./ \mathrm{mL}\right)$ in tryptone soy broth (TSB) was mixed with $900 \mu \mathrm{L}$ of TSB with or without $50 \mathrm{mg} / \mathrm{mL}$ of ABSSE followed by a $2 \mathrm{~h}$ incubation at $28^{\circ} \mathrm{C}$. Then, $100 \mu \mathrm{L}$ of mixture was spread on TSA and incubated $16 \mathrm{~h}$ at $28^{\circ} \mathrm{C}$. Colony counts from triplicate plates were recorded and data are shown as the means \pm standard errors of the mean. Significant differences from the control group are denoted by asterisks $(p<0.05$, paired-sample $t$-test). C.F.U. $=$ colony forming unit.

Table 4. Proximate composition of the experimental diets.

\begin{tabular}{cccc}
\hline $\begin{array}{c}\text { Proximate Analysis } \\
\text { (\%) }\end{array}$ & Control & ABSS * $\mathbf{1 \%}$ & ABSS * 5\% \\
\hline Crude protein & 28.0 & 27.8 & 26.8 \\
Crude lipid & 9.7 & 9.8 & 9.3 \\
Carbohydrate & 49.6 & 49.8 & 51.0 \\
Moisture & 6.4 & 6.3 & 6.6 \\
Ash & 6.3 & 6.3 & 6.3 \\
Calorie (kcal/100 g) & 398 & 399 & 395 \\
\hline
\end{tabular}

${ }^{*}$ ABSS = Agaricus blazei spent substrate.
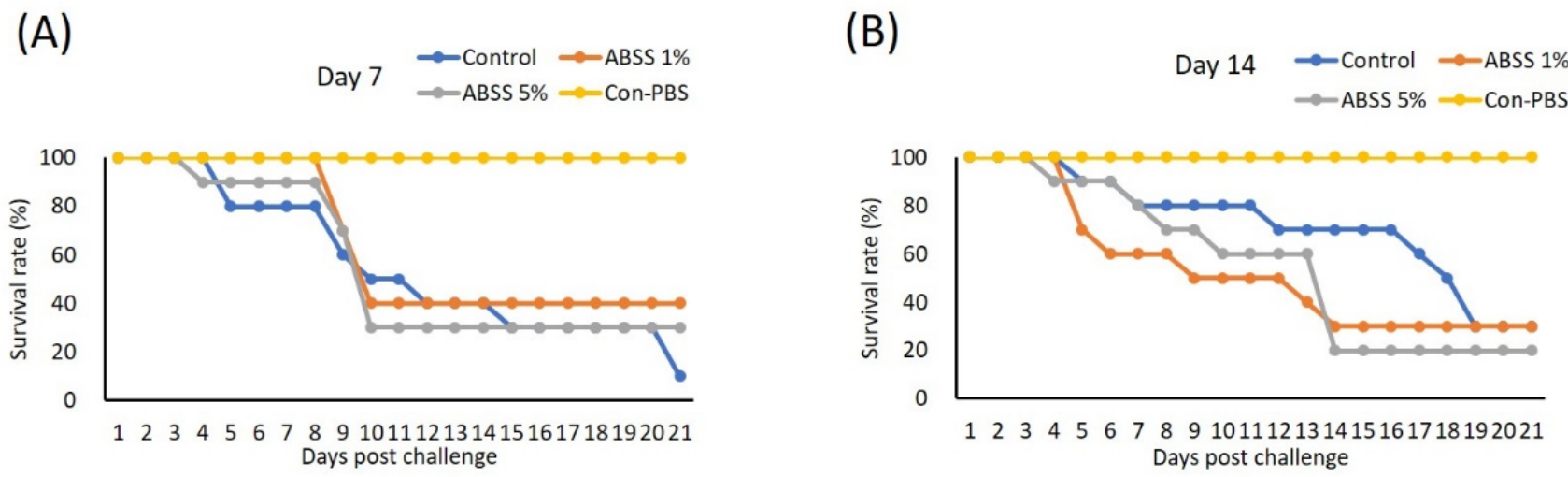

Figure 7. Fish were fed with feed containing 0 (control), $1 \%$, or $5 \%$ Agaricus blazei spent substrate (ABSS) for (A) 7 and (B) 14 days and subjected to Streptococcus agalactiae infection. A control group that injected with phosphate-buffered saline (Con-PBS) was included. Survival percentages were recorded for 21 days. $N=10$ per group. 


\subsection{ABSS Provides Sustained Protection against S. agalactiae Infection}

We conducted the second feeding trial to investigate the duration of the protective effect provided by ABSS. In this trial, fish were given feed supplemented with $0 \%$ (control) and $1 \%$ ABSS for 7 days (which provided the best protection as determined in the first trial). The feed for the experimental group was then switched to the control feed, and fish were fed for 1, 7, and 14 days prior to challenge with S. agalactiae. One day after the feed was switched, the $1 \%$ ABSS group had a higher survival rate $(46.15 \%)$ after challenge compared to the control group (21.43\%) (Figure $8 \mathrm{~A}$ ). This protective effect was sustained after 7 days, as the experimental group had more survivors (survival rate maintained at $46.15 \%$ ) post-bacterial challenge than the control group (survival rate of $21.43 \%$ ) (Figure $8 \mathrm{~B}$ ). Survivability was similar between the $1 \%$ ABSS $(27 \%)$ and control $(20 \%)$ groups after they were given the control feed for 14 days (Figure 8 C).

\section{(A)}

$\rightarrow$ Control $\rightarrow$ ABSS $1 \% \multimap-$ Con-PBS

Day 1 post feed change

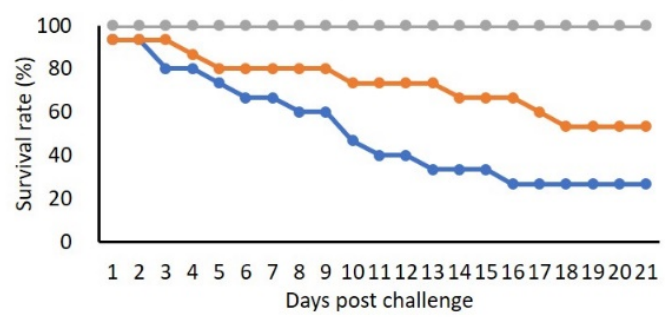

(C)

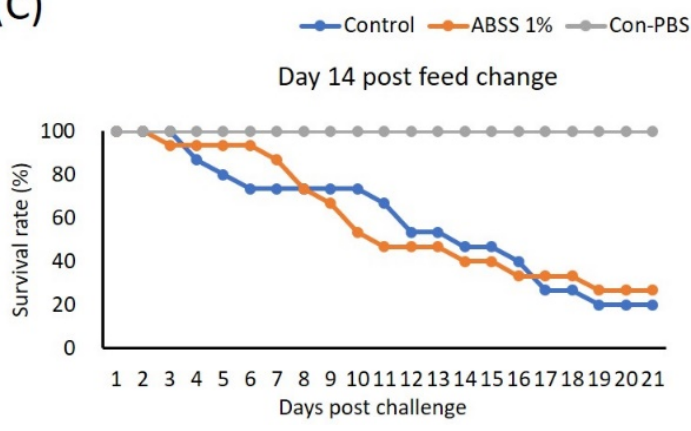

(B)

$\multimap$ Control $\longrightarrow$ ABSS $1 \% \multimap$ Con-PBS

Day 7 post feed change

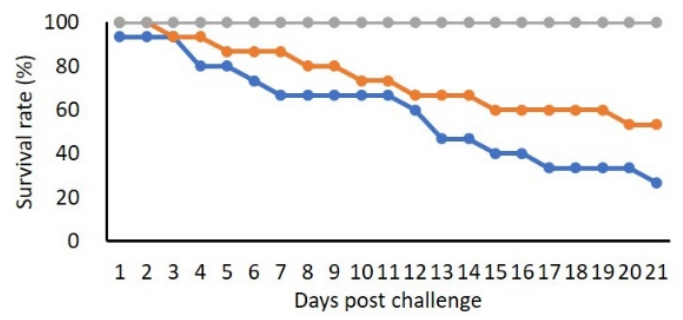

Figure 8. Fish were fed with feed containing 0 (control) and 1\% Agaricus blazei spent substrate (ABSS) for 7 days, and the feed for the experimental group was then switched to the control feed and then fish were feed for (A) 1, (B) 7, and (C) 14 days prior to challenge with Streptococcus agalactiae. A control group that was injected with phosphate-buffered saline (PBS) was included (Con-PBS). Survival rates were recorded and calculated after 21 days of observation ( $N=10$ per group).

\section{Discussion}

Compounds with bioactive properties can be extracted from the fruiting bodies of fungi or mycelial cultures [46]. A proximate analysis of the composition of the carbohydrate of ABSS indicated that polysaccharides made up $34.6 \%$ of the total carbohydrate content, and of the total carbohydrate, $1.08 \%$ was $\beta$-glucan and $6.3 \%$ was sulfated carbohydrate (Table 3). Sulphated polysaccharides extracted from A. blazei mycelia were shown to exhibit promising inhibitory effects against the attachment, penetration, and cell-to-cell spread of herpes virus types 1 and 2 [47]. Additionally, polysaccharides obtained from A. blazei mycelia showed great free radical scavenging capability [48]. With such physicochemical and biological properties, we then evaluated the potential of ABSS to induce immune responses in Nile tilapia. ABSSE was applied to the in vitro models to verify its effects on cell viability, phagocytic activity, and immune gene expression in primary hepatic and splenic macrophages and the THK cell line. The results showed that ABSSE was 
not toxic and could promote the cell viability of macrophages isolated from the liver and spleen and THK cells at concentrations of 10 and $100 \mu \mathrm{g} / \mathrm{mL}$ (Figure 1). Similar results were obtained for RAW264.7 macrophages that were treated with polysaccharides purified from A. blazei (up to $1000 \mu \mathrm{g} / \mathrm{mL}$ ) [49]. These results suggest that ABSS has low (if any) cytotoxicity and is safe for Nile tilapia. ABSSE was extracted from ABSS, containing $A$. blazei mycelium (LBP) and exopolysaccharides (EPS). It is worth noting that in this study the cell proliferation effect was not seen in the cells treated with the highest dose examined $(1000 \mu \mathrm{g} / \mathrm{mL})$. Navegantes et al. observed opposite effects of the extract LBP and EPS on the proliferation of murine splenocytes. In this previous study, the authors revealed that LBP had antiproliferative action, while the EPS showed an stimulatory effect on the splenocyte proliferation [50]. Therefore, we speculate that the unchanged or lower proliferative effects in macrophages treated with $1000 \mu \mathrm{g} / \mathrm{mL}$ ABSSE may be attributed to the presence of a certain level of LBP that antagonizes the proliferative effects mediated by EPS.

Immunomodulators can activate the immune system of aquatic animals and provide protective effects against pathogens. A phagocytosis assay has been proposed as an indicator for assessing protective mechanisms [51]. In guinea pigs, Miyagawa et al. reported that significantly higher phagocytic activity was seen in neutrophils treated with hot water extract from fruiting bodies of $A$. blazei compared with control [52]. Additionally, the hot water extract of the $A$. blazei mycelium significantly increased the activation of dendritic cells [53]. Likewise, the exopolysaccharides of A. blazei promoted the proliferation of murine splenocytes and NO production from macrophages after stimulation with Candida albicans [50]. Similarly, in the in vitro trial, ABSSE treatment increased phagocytic activity in hepatic and splenic macrophages and THK cells at $10 \mu \mathrm{g} / \mathrm{mL}$ (Figures 2 and 3), indicating that ABSS contains immunostimulatory substances.

Since $10 \mu \mathrm{g} / \mathrm{mL}$ of ABSSE could promote the phagocytic activity of macrophages from Nile tilapia, this dose was used to analyze gene expression in THK cells. The expression of proinflammatory cytokines was not induced when THK cells were directly treated with ABSSE. Notably, the expression levels of $I L-1 \beta, I L-12 b, I L-8$, and TNF- $\alpha$ were all significantly elevated when THK cells were pretreated with ABSSE followed by LPS treatment (Figure 4). Similarly, the transcript level of TNF- $\alpha$ was also higher when ABSSE-primed THK cells were stimulated with PGN (Figure 5), suggesting that ABSSE can prime THK cells (possibly via inducing M1 polarization of THK cells) and allow them to respond more strongly when they encounter invasive microbes. Although the underlying mechanisms of ABSSE priming of THK cells require further investigations, a similar phenomenon was reported by Cleary et al., whereby intraperitoneal injection of yeast glucan resulted in altered morphology of peritoneal macrophages, increased intracellular acid phosphatase, and increased LPS- and PMA-stimulated nitrogen oxide and superoxide production, respectively [54]. Likewise, Vetvika et al. reported that priming of the leukocyte $\beta 2$-integrin complement receptor type 3 (CR3) with soluble $\beta$-glucan did not stimulate neutrophils to express proinflammatory features, but induced a primed state of CR3 that targets cell-bound $\mathrm{iC} 3 \mathrm{~b}$ and mediates the cytotoxicity of iC3b-target cells [55].

A previous study showed that direct treatment of $A$. blazei water extract could boost the transcript level of $I L-1 \beta$ and facilitate NLRP3 inflammasome-mediated IL-1 $\beta$ secretion in human THP-1 macrophages [56]. Similarly, the water extract of A. blazei can induce the production of IL-1 $\beta$ and IL- 6 in human monocytes and umbilical vein endothelial cells in a dose-dependent manner [57]. TNF- $\alpha$ secretion and nitric oxide (NO) production were not induced when macrophages derived from rat bone marrow were stimulated with water extracts of the mycelium of A. blazei at doses lower than $100 \mu \mathrm{g} / \mathrm{mL}$ [16]. The responses of the primed bone-marrow-derived macrophages after bacterial ligand treatments were of interest in the present study. The increased antimicrobial responses from A. blazei extracts may be due to the nature of the stimulatory effects of $\beta$-glucans through the activation of toll-like receptor (TLR) 2 [58] and dectin-1 [59], as well as the initiation of cytokine synthesis and secretion by mammalian macrophages [16]. However, direct evidence on the recognition of $\beta$-glucan by these pattern recognition receptors in fish is still 
lacking. In the present study, the $\beta$-glucan content accounted for only $1 \%$ of the ABSSE, which means there was only $100 \mathrm{ng} / \mathrm{mL}$ of $\beta$-glucan $(1 \%$ of $10 \mu \mathrm{g} / \mathrm{mL})$ in the conditioned medium for cell treatment. This dose of $\beta$-glucan is much lower than that used in previous studies (e.g., $25 \mu \mathrm{g} / \mathrm{mL}$ ) to stimulate macrophages in fish such as common carp (Cyprinus carpio L.) [60], suggesting that $\beta$-glucan may not be the major substance responsible for those changes. Similarly, other studies have shown that galactomannan polysaccharide from Morchella esculenta can increase NF-kB-driven luciferase expression in human THP-1 monocytic cells [61], and a fucose-containing polysaccharide fraction (F3) fractionated from the water-soluble Ganoderma lucidum extracts was able to enhance cell differentiation of THP-1 cells [62]. Hence, $\beta$-glucan may not be the only substance responsible for the effects observed in the present study.

Although the mechanisms behind the immunomodulatory effects of ABSSE are unclear, bioactive compounds, including sulfated polysaccharides, protein-polysaccharide complexes, phenolic compounds, and organic acids, from A. blazei mycelia may contribute to the antimicrobial effects [14]. Researchers have found several phenolic compounds and organic acids from A. blazei mycelia with antioxidant activity [63]. Cardozo et al. demonstrated that a sulfated polysaccharide extracted from A. blazei mycelia showed promising inhibitory activity against herpes simplex viruses 1 and 2 by inhibiting virus attachment, penetration, and cell-to-cell spread, and by reducing the expression of viral genes [47]. Furthermore, strong inhibition of the cytopathic effects on Vero cells induced by western equine encephalitis virus was observed in the cells treated with water extracts of cultured A. blazei mycelia [64]. Mushrooms have been proposed as natural antibiotics, since they contain compounds such as anthraquinone, steroids, terpenes, and sesquiterpenes, as well as derivatives of benzoic acid, oxalic acid, quinolines, peptides, and proteins [65]. Few studies have addressed the antimicrobial properties of A. blazei [66], and most studies have used commercially available products (e.g., AndoSan ${ }^{\mathrm{TM}}$, Immunopharma AS) [67] or the extracts from fruiting bodies [68-70]. The antimicrobial functions of A. blazei were determined by in vitro tests $[68,69,71]$, which indicated that the mushroom extract can inhibit the growth of microorganisms such as S. pneumoniae [72]. However, to the best of our knowledge, no studies have verified the antimicrobial activity of ABSS. Here, we show for the first time that the water extract of ABSS can inhibit the growth of S. agalactiae (Figure 6), indicating that ABSS contains water-soluble substances that induce the immune responses of immune cells and that ABSS has antibacterial properties.

Bernardshaw and colleagues demonstrated that orally ingested water containing $A$. blazei protected NIH/OlaHsd mice against systemic S. pneumoniae 6B infection [72]. In aquaculture, dietary administration of Cordyceps militaris spent mushroom substrate protects Nile tilapia from S. agalactiae infection [34]. Since our in vitro experiments suggested that ABSS contains prophylactic agents against infectious diseases, its protection efficacy was examined in vivo. Dietary administration of feed with $1 \%$ ABSS for seven days enhanced the survival rate of Nile tilapia compared to fish on the control diet, but a prolonged feeding regime (feed for 14 days) did not improve the survival rate after challenge with S. agalactiae. Importantly, the addition of feed additives would increase the cost of cultured seafood production and may hinder the use of other products by farmers. Short-term use of feed immunomodulators that can provide long-term protection for aquatic animals would be more appealing. To this end, we tested whether the protective effects against S. agalactiae would last after the feed is switched to the control diet after ingesting $1 \%$ ABSS for seven days. Surprisingly, the survival rate was maintained for seven days after the feed was changed (Figure 8). Therefore, ABSS is suggested as a novel and cost-effective functional feed additive for Nile tilapia to provide protection against $S$. agalactiae. Of interest, it is assumed that innate immune responses are generally short-lived, but we observed longlived effects on innate immunity after administering ABSS, suggesting a phenomenon of trained innate immunity that is proposed to play a pronounced role in the immune system of fish [73]. Similarly, feeding sea bass (Dicentrarchus labrax) for 2 weeks every 3 months with $\beta$-glucan-supplemented diets followed by 10 weeks of control diet resulted 
in elevated serum complement and lysozyme activities compared to those of fish in the control group [74]. Likewise, orange-spotted grouper (Epinephelus coioides) fed with a diet containing mushroom $\beta$-glucan mixture for 12 days showed higher survival rates after challenge with Vibrio alginolyticus 15 days after changing the diets back to a control diet [75]. The present and previous studies suggest long-lived effects stimulated by $\beta$-glucans and mushroom polysaccharides, possibly attributed to the key players, namely macrophages. Fundamental knowledge of the mechanisms of induction of trained immunity via dietary ingestion of immunoregulators is required and would benefit the use of immunoregulators as feed additives for aquatic animals.

\section{Conclusions}

The spent substrate of $A$. blazei acts as an immunomodulator to enhance the phagocytic activity and prime macrophages to induce the expression of proinflammatory cytokines when encountering microbes. We suggest that the spent substrate of A. blazei is a costeffective feed additive for fish that protects Nile tilapia against $S$. agalactiae infection.

Author Contributions: Conceptualization, C.-C.T.; methodology, C.-C.T.; formal analysis, Y.-S.W. and P.-T.L.; investigation, Y.-S.W. and P.-T.L.; resources, J.-Y.L. and M.-C.L.; writing—original draft preparation, P.-T.L.; writing-review and editing, P.-T.L.; supervision, M.-C.L.; project administration, J.-Y.L.; funding acquisition, J.-Y.L. and M.-C.L. All authors have read and agreed to the published version of the manuscript.

Funding: This study was supported by a grant from the Ministry of Science and Technology (MOST) 108-2313-B-020-005-MY3, Taiwan; a grant from the Zuoying Branch of Kaohsiung Armed Forces General Hospital KAFGH-ZY-A-109035, Taiwan; and a grant from the Council of Agriculture, Executive Yuan 108AS-14.3.1-ST-a4, Taiwan.

Institutional Review Board Statement: The animal experiments were approbated by the Institutional Animal Care and Use Committee at NTOU (Approval number: 109005).

Informed Consent Statement: Not applicable.

Data Availability Statement: The data presented in this study are available upon request from the corresponding author.

Acknowledgments: We thank Leone Ligalevu, Po-Yu Chiu, Kuan-Yu Liu, and Hsu Keng-Chen for technical support.

Conflicts of Interest: The authors declare that they have no conflict of interest in this work.

\section{References}

1. FAO. FAO Report on the State of Global Fisheries and Aquaculture 2020; FAO: Rome, Italy, 2020.

2. El-Sayed, A.-F.M. Current state and future potential. In Tilapia Culture, 2nd ed.; El-Sayed, A.-F.M., Ed.; Academic Press: Cambridge, MA, USA, 2020; Chapter 1; pp. 1-20.

3. Abu-Elala, N.; Ali, T.; Ragaa, N.; Ali, S.; Abd-Elsalam, R.; Younis, N.; Abdel-Moneam, D.; Hamdien, A.; Bonato, M.; Dawood, M. Analysis of the Productivity, Immunity, and Health Performance of Nile Tilapia (Oreochromis niloticus) Broodstock-fed Dietary Fermented Extracts Sourced from Saccharomyces cerevisiae (Hilyses): A Field Trial. Animals 2021, 11, 815. [CrossRef]

4. Su, Y.-L.; Feng, J.; Li, Y.-W.; Bai, J.-S.; Li, A.-X. Development of a quantitative PCR assay for monitoring Streptococcus agalactiae colonization and tissue tropism in experimentally infected tilapia. J. Fish Dis. 2016, 39, 229-238. [CrossRef]

5. Neamat-Allah, A.N.; Mahmoud, E.; El Hakim, Y.A. Efficacy of dietary Nano-selenium on growth, immune response, antioxidant, transcriptomic profile and resistance of Nile tilapia, Oreochromis niloticus against Streptococcus iniae infection. Fish Shellfish Immunol. 2019, 94, 280-287. [CrossRef] [PubMed]

6. Aly, S.M.; Albutti, A.S.; Rahmani, A.H.; Atti, N.M.A. The response of New-season Nile tilapia to Aeromonas hydrophila vaccine. Int. J. Clin. Exp. Med. 2015, 8, 4508-4514.

7. Iregui, C.A.; Guarín, M.; Tibatá, V.M.; Ferguson, H.W. Novel brain lesions caused by Edwardsiella tarda in a red tilapia (Oreochromis spp.). J. Veter. Diagn. Investig. 2012, 24, 446-449. [CrossRef]

8. Hsieh, C.; Tung, M.; Tu, C.; Chang, C.; Tsai, S. Enzootics of visceral granulomas associated with Francisella-like organism infection in tilapia (Oreochromis spp.). Aquaculture 2006, 254, 129-138. [CrossRef]

9. Rattanachaikunsopon, P.; Phumkhachorn, P. Protective effect of clove oil-supplemented fish diets on experimental Lactococcus garvieae infection in tilapia. Biosci. Biotechnol. Biochem. 2009, 73, 2085-2089. [CrossRef] [PubMed] 
10. Acharya, V.; Chakraborty, H.J.; Rout, A.K.; Balabantaray, S.; Behera, B.K.; Das, B.K. Structural Characterization of Open Reading Frame-Encoded Functional Genes from Tilapia Lake Virus (TiLV). Mol. Biotechnol. 2019, 61, 945-957. [CrossRef]

11. Pridgeon, J.W.; Klesius, P.H. Major bacterial diseases in aquaculture and their vaccine development. In Animal Science Review; CABI: Boston, MA, USA, 2012; pp. 141-156. [CrossRef]

12. Liu, G.; Zhu, J.; Chen, K.; Gao, T.; Yao, H.; Liu, Y.; Zhang, W.; Lu, C. Development of Streptococcus agalactiae vaccines for tilapia. Dis. Aquat. Org. 2016, 122, 163-170. [CrossRef] [PubMed]

13. Bromage, E.; Owens, L. Infection of barramundi Lates calcarifer with Streptococcus iniae: Effects of different routes of exposure. Dis. Aquat. Org. 2002, 52, 199-205. [CrossRef]

14. Firenzuoli, F.; Gori, L.; Lombardo, G. The Medicinal Mushroom Agaricus blazei Murrill: Review of Literature and PharmacoToxicological Problems. Evid. Based Complement. Altern. Med. 2008, 5, 3-15. [CrossRef] [PubMed]

15. Hetland, G.; Tangen, J.-M.; Mahmood, F.; Mirlashari, M.R.; Nissen-Meyer, L.S.H.; Nentwich, I.; Therkelsen, S.P.; Tjønnfjord, G.E.; Johnson, E. Antitumor, Anti-inflammatory and Antiallergic Effects of Agaricus blazei Mushroom Extract and the Related Medicinal Basidiomycetes Mushrooms, Hericium erinaceus and Grifola frondosa: A Review of Preclinical and Clinical Studies. Nutrients 2020, 12, 1339. [CrossRef]

16. Sorimachi, K.; Akimoto, K.; Ikehara, Y.; Inafuku, K.; Okubo, A.; Yamazaki, S. Secretion of TNF- $\alpha$, IL-8 and Nitric Oxide by Macrophages Activated with Agaricus blazei Murill Fractions In Vitro. Cell Struct. Funct. 2001, 26, 103-108. [CrossRef] [PubMed]

17. Watanabe, T.; Kawashita, A.; Ishi, S.; Mazumder, T.K.; Nagai, S.; Tsuji, K.; Dan, T. Antihypertensive Effect of GAMMAAminobutyric Acid-Enriched Agaricus blazei on Mild Hypertensive Human Subjects. Nippon. Shokuhin Kagaku Kogaku Kaishi 2003, 50, 167-173. [CrossRef]

18. Kweon, M.H.; Kwon, S.T.; Kwon, S.H.; Ma, M.S.; Park, Y.I. Lowering effects in plasma cholesterol and body weight by mycelial extracts of two mushrooms: Agaricus blazai and Lentinus edodes. Korean J. Microbiol. Biotechnol. 2002, 30, 402-409.

19. Inuzuka, H.; Yoshida, T. Clinical utility of ABCL (Agalicus Mushroom Extract) treatment for C-type hepatitis. Jpn. Pharmacol. Ther. 2002, 30, 103-107.

20. Takaku, T.; Kimura, Y.; Okuda, H. Isolation of an Antitumor Compound from Agaricus blazei Murill and Its Mechanism of Action. J. Nutr. 2001, 131, 1409-1413. [CrossRef] [PubMed]

21. Reis, F.S.; Martins, A.; Barros, L.; Ferreira, I. Antioxidant properties and phenolic profile of the most widely appreciated cultivated mushrooms: A comparative study between in vivo and in vitro samples. Food Chem. Toxicol. 2012, 50, 1201-1207. [CrossRef]

22. Ahmed, M.; Abdullah, N.; Shuib, A.S.; Razak, S.A. Influence of raw polysaccharide extract from mushroom stalk waste on growth and $\mathrm{pH}$ perturbation induced-stress in Nile tilapia, Oreochromis niloticus. Aquaculture 2017, 468, 60-70. [CrossRef]

23. Phan, C.-W.; Sabaratnam, V. Potential uses of spent mushroom substrate and its associated lignocellulosic enzymes. Appl. Microbiol. Biotechnol. 2012, 96, 863-873. [CrossRef]

24. Mayolo-Deloisa, K.; Trejo-Hernández, M.D.R.; Rito-Palomares, M. Recovery of laccase from the residual compost of Agaricus bisporus in aqueous two-phase systems. Process Biochem. 2009, 44, 435-439. [CrossRef]

25. Munusamy, U.; Sabaratnam, V.; Muniandy, S.; Abdullah, N.; Pandey, A.; Jones, E. Biodegradation of Polycyclic Aromatic Hydrocarbons by Laccase of Pycnoporus sanguineus and Toxicity Evaluation of Treated PAH. Biotechnology 2008, 7, 669-677. [CrossRef]

26. Trejo-Hernandez, M.; Lopez-Munguia, A.; Ramirez, R.Q. Residual compost of Agaricus bisporus as a source of crude laccase for enzymic oxidation of phenolic compounds. Process Biochem. 2001, 36, 635-639. [CrossRef]

27. Chiu, S.; Ching, M.; Fong, K.; Moore, D. Spent oyster mushroom substrate performs better than many mushroom mycelia in removing the biocide pentachlorophenol. Mycol. Res. 1998, 102, 1553-1562. [CrossRef]

28. Adamović, M.; Grubić, G.; Milenković, I.; Jovanović, R.; Protić, R.; Sretenović, L.; Stoićević, L. The biodegradation of wheat straw by Pleurotus ostreatus mushrooms and its use in cattle feeding. Anim. Feed. Sci. Technol. 1998, 71, 357-362. [CrossRef]

29. Vallejos-Vidal, E.; Reyes-López, F.; Teles, M.; MacKenzie, S. The response of fish to immunostimulant diets. Fish Shellfish. Immunol. 2016, 56, 34-69. [CrossRef] [PubMed]

30. Yudiati, E.; Isnansetyo, A.; Handayani, C.R. Alginate from Sargassum siliquosum Simultaneously Stimulates Innate Immunity, Upregulates Immune Genes, and Enhances Resistance of Pacific White Shrimp (Litopenaeus vannamei) against White Spot Syndrome Virus (WSSV). Mar. Biotechnol. 2019, 21, 503-514. [CrossRef]

31. Van Doan, H.; Hoseinifar, S.H.; Dawood, M.; Chitmanat, C.; Tayyamath, K. Effects of Cordyceps militaris spent mushroom substrate and Lactobacillus plantarum on mucosal, serum immunology and growth performance of Nile tilapia (Oreochromis niloticus). Fish Shellfish. Immunol. 2017, 70, 87-94. [CrossRef]

32. Kiron, V. Fish immune system and its nutritional modulation for preventive health care. Anim. Feed Sci. Technol. 2012, 173, 111-133. [CrossRef]

33. Pohlenz, C.; Gatlin, D.M. Interrelationships between fish nutrition and health. Aquaculture 2014, 431, 111-117. [CrossRef]

34. Van Doan, H.; Hoseinifar, S.H.; Tapingkae, W.; Chitmanat, C.; Mekchay, S. Effects of Cordyceps militaris spent mushroom substrate on mucosal and serum immune parameters, disease resistance and growth performance of Nile tilapia, (Oreochromis niloticus). Fish Shellfish. Immunol. 2017, 67, 78-85. [CrossRef]

35. Horm, V.; Ohga, S. Potential of Compost with Some Added Supplementary Materials on the Development of Agaricus blazei Murill. J. Fac. Agric. Kyushu Univ. 2008, 53, 417-422. [CrossRef] 
36. Largeteau, M.L.; Llarena-Hernandez, R.C.; Regnault-Roger, C.; Savoie, J.-M. The medicinal Agaricus mushroom cultivated in Brazil: Biology, cultivation and non-medicinal valorisation. Appl. Microbiol. Biotechnol. 2011, 92, 897-907. [CrossRef] [PubMed]

37. Rózsa, S.; Măniuțiu, D.-N.; Poșta, G.; Gocan, T.-M.; Andreica, I.; Bogdan, I.; Lazăr, V. Influence of the Culture Substrate on the Agaricus blazei Murrill Mushrooms Vitamins Content. Plants 2019, 8, 316. [CrossRef]

38. Cunniff, P.; AOAC International. Official Methods of Analysis of AOAC International; AOAC International: Gaithersburg, MD, USA, 1997.

39. Bhadja, P.; Tan, C.-Y.; Ouyang, J.-M.; Yu, K. Repair Effect of Seaweed Polysaccharides with Different Contents of Sulfate Group and Molecular Weights on Damaged HK-2 Cells. Polymers 2016, 8, 188. [CrossRef]

40. Wu, Y.-S.; Nan, F.-H.; Huang, S.-L.; Hsiao, C.-M.; Lai, K.-C.; Lu, C.-L.; Chen, S.-N. Studies of macrophage cellular response to the extracellular hydrogen peroxide by tilapia model. Fish Shellfish Immunol. 2014, 36, 459-466. [CrossRef] [PubMed]

41. Wen, C.-M. Development and characterization of a cell line from tilapia head kidney with melanomacrophage characteristics Fish Shellfish. Immunol. 2016, 49, 442-449. [CrossRef]

42. Lee, P.-T.; Wen, C.-M.; Nan, F.-H.; Yeh, H.-Y.; Lee, M.-C. Immunostimulatory effects of Sarcodia suiae water extracts on Nile tilapia Oreochromis niloticus and its resistance against Streptococcus agalactiae. Fish Shellfish. Immunol. 2020, 103, 159-168. [CrossRef]

43. Trung, N.B.; Lee, P.-T. Functional characterization of myeloid differentiation factor 88 in Nile tilapia (Oreochromis niloticus). Comp. Biochem. Physiol. Part B Biochem. Mol. Biol. 2020, 250, 110485. [CrossRef] [PubMed]

44. Wang, T.; Diaz-Rosales, P.; Costa, M.M.; Campbell, S.; Snow, M.; Collet, B.; Martin, S.; Secombes, C.J. Functional Characterization of a Nonmammalian IL-21: Rainbow TroutOncorhynchus mykissIL-21 Upregulates the Expression of the Th Cell Signature Cytokines IFN- $\gamma$, IL-10, and IL-22. J. Immunol. 2010, 186, 708-721. [CrossRef]

45. Hao, H.; Fu, M.; Yan, R.; He, B.; Li, M.; Liu, Q.; Cai, Y.; Zhang, X.; Huang, R. Chemical composition and immunostimulatory properties of green alga Caulerpa racemosa var peltata. Food Agric. Immunol. 2019, 30, 937-954. [CrossRef]

46. Bernart, M.W. Mushrooms. Cultivation, Nutritional Value, Medicinal Effect, and Environmental Impact, 2nd ed.; Chang, S.-T., Miles, P.G., Eds.; CRC Press: Boca Raton, FL, USA, 2004; 451p. [CrossRef]

47. Cardozo, F.T.G.D.S.; Camelini, C.M.; Mascarello, A.; Rossi, M.J.; Nunes, R.J.; Barardi, C.R.M.; de Mendonça, M.M.; Simões, C.M.O Antiherpetic activity of a sulfated polysaccharide from Agaricus brasiliensis mycelia. Antivir. Res. 2011, 92, 108-114. [CrossRef]

48. Ker, Y.-B.; Chen, K.-C.; Chyau, C.-C.; Chen, C.-C.; Guo, J.-H.; Hsieh, C.-L.; Wang, H.-E.; Peng, C.-C.; Chang, C.-H.; Peng, R.Y. Antioxidant Capability of Polysaccharides Fractionated from Submerge-Cultured Agaricus blazei Mycelia. J. Agric. Food Chem. 2005, 53, 7052-7058. [CrossRef]

49. Cheng, F.; Yan, X.; Zhang, M.; Chang, M.; Yun, S.; Meng, J.; Liu, J.; Feng, C.-P. Regulation of RAW 264.7 cell-mediated immunity by polysaccharides from Agaricus blazei Murill via the MAPK signal transduction pathway. Food Funct. 2017, 8, 1475-1480. [CrossRef] [PubMed]

50. Navegantes, K.C.; Albuquerque, R.F.V.; Dalla-Santa, H.S.; Soccol, C.R.; Monteiro, M.C. Agaricus brasiliensismycelium and its polysaccharide modulate the parameters of innate and adaptive immunity. Food Agric. Immunol. 2013, 24, 393-408. [CrossRef]

51. Wang, W.; Sun, J.; Liu, C.; Xue, Z. Application of immunostimulants in aquaculture: Current knowledge and future perspectives. Aquac. Res. 2017, 48, 1-23. [CrossRef]

52. Miyagawa, M.; Hirono, Y.; Kawazoe, A.; Shigeyoshi, E.; Nose, M.; Sakura, M.; Pinkerton, K.E.; Takeuchi, M. Effect of Hot Water Extract from Agaricus blazei Murill on Chemotaxis of Neutrophils. J. Cosmet. Dermatol. Sci. Appl. 2013, 3, 12-17. [CrossRef]

53. Yasuma, T.; Toda, M.; Kobori, H.; Tada, N.; D'Alessandro-Gabazza, C.; Gabazza, E. Subcritical Water Extracts from Agaricus blazei Murrill's Mycelium Inhibit the Expression of Immune Checkpoint Molecules and Axl Receptor. J. Fungi 2021, 7, 590. [CrossRef]

54. Cleary, J.A.; Kelly, G.E.; Husband, A.J. The effect of molecular weight and $\beta-1,6$-linkages on priming of macrophage function in mice by (1,3)- $\beta$-d-glucan. Immunol. Cell Biol. 1999, 77, 395-403. [CrossRef] [PubMed]

55. Vetvicka, V.; Thornton, B.P.; Ross, G.D. Soluble beta-glucan polysaccharide binding to the lectin site of neutrophil or natural killer cell complement receptor type 3 (CD11b/CD18) generates a primed state of the receptor capable of mediating cytotoxicity of iC3b-opsonized target cells. J. Clin. Investig. 1996, 98, 50-61. [CrossRef]

56. Huang, T.-T.; Ojcius, D.; Young, J.D.; Wu, Y.-H.; Ko, Y.-F.; Wong, T.-Y.; Wu, C.-Y.; Lu, C.-C.; Lai, H.-C. The Anti-Tumorigenic Mushroom Agaricus blazei Murill Enhances IL-1 $\beta$ Production and Activates the NLRP3 Inflammasome in Human Macrophages. PLoS ONE 2012, 7, e41383. [CrossRef]

57. Bernardshaw, S.; Hetland, G.; Ellertsen, L.K.; Tryggestad, A.M.A.; Johnson, E. An Extract of the Medicinal Mushroom Agaricus blazei Murill Differentially Stimulates Production of Pro-inflammatory Cytokines in Human Monocytes and Human Vein Endothelial Cells In Vitro. Inflammation 2006, 29, 147-153. [CrossRef] [PubMed]

58. Underhill, D.; Ozinsky, A.; Hajjar, A.; Stevens, A.; Wilson, C.B.; Bassetti, M.; Aderem, A. The Toll-like receptor 2 is recruited to macrophage phagosomes and discriminates between pathogens. Nature 1999, 401, 811-815. [CrossRef]

59. Brown, G.D.; Herre, J.; Williams, D.L.; Willment, J.; Marshall, A.; Gordon, S. Dectin-1 Mediates the Biological Effects of $\beta$-Glucans. J. Exp. Med. 2003, 197, 1119-1124. [CrossRef] [PubMed]

60. Petit, J.; Bailey, E.C.; Wheeler, R.T.; De Oliveira, C.A.F.; Forlenza, M.; Wiegertjes, G.F. Studies Into $\beta$-Glucan Recognition in Fish Suggests a Key Role for the C-Type Lectin Pathway. Front. Immunol. 2019, 10, 280. [CrossRef] [PubMed]

61. Duncan, C.J.G.; Pugh, N.; Pasco, D.S.; Ross, S.A. Isolation of a Galactomannan That Enhances Macrophage Activation from the Edible Fungus Morchella esculenta. J. Agric. Food Chem. 2002, 50, 5683-5685. [CrossRef] 
62. Hsu, J.-W.; Huang, H.-C.; Chen, S.-T.; Wong, C.-H.; Juan, H.-F. Ganoderma lucidumPolysaccharides Induce Macrophage-like Differentiation in Human Leukemia THP-1 Cells via Caspase and p53 Activation. Evid. Based Complement. Altern. Med. 2011, 2011, 358717. [CrossRef]

63. Carvajal, A.E.S.; Koehnlein, E.A.; Soares, A.A.; Eler, G.J.; Nakashima, A.T.A.; Bracht, A.; Peralta, R.M. Bioactives of fruiting bodies and submerged culture mycelia of Agaricus brasiliensis (A. blazei) and their antioxidant properties. LWT Food Sci. Technol. 2012, 46, 493-499. [CrossRef]

64. Sorimachi, K.; Ikehara, Y.; Maezato, G.; Okubo, A.; Yamazaki, S.; Akimoto, K.; Niwa, A. Inhibition by Agaricus blazei Murill Fractions of Cytopathic Effect Induced by Western Equine Encephalitis (WEE) Virus on VERO Cells In Vitro. Biosci. Biotechnol. Biochem. 2001, 65, 1645-1647. [CrossRef]

65. Alves, M.J.; Ferreira, I.; Dias, J.; Teixeira, V.; Martins, A.; Pintado, M.M. A Review on Antimicrobial Activity of Mushroom (Basidiomycetes) Extracts and Isolated Compounds. Planta Med. 2012, 78, 1707-1718. [CrossRef]

66. Lima, C.U.; Gris, E.F.; Karnikowski, M. Antimicrobial properties of the mushroom Agaricus blazei-Integrative review. Rev. Bras. Farm. 2016, 26, 780-786. [CrossRef]

67. Bernardshaw, S.; Hetland, G.; Grinde, B.; Johnson, E. An extract of the mushroom Agaricus blazei Murill protects against lethal septicemia in a mouse model of fecal peritonitis. Shock 2006, 25, 420-425. [CrossRef] [PubMed]

68. Osaki, Y.; Kato, T.; Yamamoto, K.; Okubo, J.; Miyazaki, T. Antimutagenic and Bactericidal Substances in the Fruit Body of a Basidiomycete Agaricus blazei, Jun-17. Yakugaku Zasshi J. Pharm. Soc. Jpn. 1994, 114, 342-350. [CrossRef] [PubMed]

69. Stojković, D.; Reis, F.S.; Glamočlija, J.; Ćirić, A.; Barros, L.; Van Griensven, L.J.L.D.; Ferreira, I.C.F.R.; Soković, M. Cultivated strains of Agaricus bisporus and A. brasiliensis: Chemical characterization and evaluation of antioxidant and antimicrobial properties for the final healthy product-Natural preservatives in yoghurt. Food Funct. 2014, 5, 1602-1612. [CrossRef]

70. Soković, M.; Ćirić, A.; Glamočlija, J.; Nikolić, M.; Van Griensven, L.J.L.D. Agaricus blazei Hot Water Extract Shows Anti Quorum Sensing Activity in the Nosocomial Human Pathogen Pseudomonas Aeruginosa. Molecules 2014, 19, 4189-4199. [CrossRef]

71. Mazzutti, S.; Ferreira, S.R.S.; Riehl, C.A.; Smania, A.; Smania, F.A.; Martínez, J. Supercritical fluid extraction of Agaricus brasiliensis: Antioxidant and antimicrobial activities. J. Supercrit. Fluids 2012, 70, 48-56. [CrossRef]

72. Bernardshaw, S.; Johnson, E.; Hetland, G. An Extract of the Mushroom Agaricus blazei Murill Administered Orally Protects against Systemic Streptococcus pneumoniae Infection in Mice. Scand. J. Immunol. 2005, 62, 393-398. [CrossRef] [PubMed]

73. Petit, J.; Wiegertjes, G.F. Long-lived effects of administering $\beta$-glucans: Indications for trained immunity in fish. Dev. Comp. Immunol. 2016, 64, 93-102. [CrossRef]

74. Bagni, M.; Archetti, L.; Amadori, M.; Marino, G. Effect of Long-term Oral Administration of an Immunostimulant Diet on Innate Immunity in Sea Bass (Dicentrarchus labrax). J. Veter-Med. Ser. B 2000, 47, 745-751. [CrossRef]

75. Chang, C.-S.; Huang, S.-L.; Chen, S.; Chen, S.-N. Innate immune responses and efficacy of using mushroom beta-glucan mixture (MBG) on orange-spotted grouper, Epinephelus coioides, aquaculture. Fish Shellfish Immunol. 2013, 35, 115-125. [CrossRef] 